\title{
PENERAPAN TEKNOLOGI BUDIDAYA DAN KOMPONEN KAWASAN PENGEMBANGAN SAPI POTONG DI KABUPATEN RAJA AMPAT
}

\author{
Mochammad S. Soltief ${ }^{1 *}$, Asnath M Fuah ${ }^{2}$, Rudy Priyanto ${ }^{2}$ \\ ${ }^{1}$ Dinas Penanaman Modal dan PTSP Kabupaten Raja Ampat \\ Jln. Kompleks Kantor Bupati Raja Ampat, Waisai, Kode Pos. 98482 \\ ${ }^{2}$ Fakultas Peternakan, Institut Pertanian Bogor \\ Jln. Agatis, Kampus IPB Darmaga, Dramaga - Bogor, Kode Pos. 16680 \\ *Email : otief_said@gmail.com
}

\begin{abstract}
ABSTRAK
Penelitian ini bertujuan untuk mengetahui penerapan teknologi budidaya dan komponen-komponen kawasan dalam kaitannya dengan pengembangan sapi potong di kabupaten Raja Ampat. Penelitian ini menggunakan metode survei dengan cara pengamatan langsung di lapangan dan melakukan wawancara terhadap 218 responden yang memiliki sapi potong di Kampung Sakabu, Kalobo dan Waijan. Peubah yang diamati dalam penelitian ini meliputi: lahan dan sistem penggunaan lahan, pola manajemen produksi sapi potong; meliputi reproduksi, pemeliharaan dan perkandangan, pakan, penyakit dan kesehatan ternak, pendampingan, sarana dan prasarana, pasca panen dan pemasaran hasil, karakteristik kelembagaan dan kebijakan pemerintah; meliputi kelembagaan peternak dan permodalan, program-program pemerintah daerah yang menunjang pegembangan peternakan sapi potong. Hasil penelitian menunjukkan bahwa sistem pemeliharaan masih bersifat ekstensif dengan cara digembalakan pada areal padang pengembalaan, hutan, persawahan atau perkebunan; peternak sapi potong belum melaksanakan seleksi ternak secara terarah, dan sistem perkawianan umumnya masih secara alami; aplikasi teknologi pengolahan pakan belum diterapkan secara baik dan benar. Berdasarkan total skor yang diperoleh, kawasan pembibitan dan penggemukan sapi potong di kabupaten Raja Ampat adalah dibawah 500, yang diklasifikasikan sebagai kawasan baru.
\end{abstract}

Kata kunci: Teknologi budidaya, kawasan pengembangan, sapi potong

\section{APPLICATION OF LIVESTOCK BREEDING TECHNOLOGY AND THE AREA DEVELOPMENT COMPONENTS OF BEEF CATTLE IN RAJA AMPAT REGENCY}

\begin{abstract}
The aims of this study were to determine the application of livestock breeding technology and the specific components in order to develop strategic planning for cattle production in Raja Ampat district. A total of 218 farmer from three different villages, namely Sakabu, Kalobo, and Waijan were observed and intervewied.The land and their use system, a pattern of cattle management production, and the characteristic of institutional and government regulation were observed as study variables. These three major variables were divided to collect the comprehensive data. The second variables covered reproduction, maintenance and housing, feed, disease and health, assistance, facilities and infrastructure, postharvest handling, and marketing. The third consist of farmer organization and capital resources and regional support system to enhance cattle production. The results showed : (1) pastoral system was common where farmers allows their cattle to graze freely in various places such as grassland, forest, rice fields or farmland, (2) the selective breeding practice was unadopted instead of the traditional mating, and (3) application of feeding technology not applied properly.Raja Ampat, a center of cattle breeding and fattening, was identified as a new prospective development area based on total score $(<500)$.
\end{abstract}

Key words: Breeding technology, development area, beef cattle 


\section{PENDAHULUAN}

Sebagai daerah pemekaran, pemerintah Kabupaten Raja Ampat berusaha untuk membangun berbagai sektor dengan memanfaatkan potensi alam yang ada seoptimal mungkin. Salah satunya adalah sub sektor peternakan dengan komoditas sapi potong, yang merupakan salah satu komoditi yang cukup menjanjikan untuk dikembangkan di Kabupaten Raja Ampat. Selain sebagai penghasil daging, sapi juga berfungsi menciptakan lapangan kerja (Putu dkk., 1997), sumber tenaga kerja, daur ulang nutrisi (nutrient recycling), kotoran sebagai pupuk dan gas, serta fungsi lainnya dalam membantu mempertahankan kelangsungan hidup dan kelestarian fungsi lingkungan (Deptan, 2002).

Kondisi wilayah yang luas memungkinkan pembentukan/pengembangan suatu kawasan budidaya sapi potong guna peningkatan ketahanan pangan untuk mewakili kebutuhan masyarakat akan protein hewani, peningkatan pendapatan petani peternak dan pendapatan asli daerah (PAD). Beberapa faktor yang dapat dijadikan sebagai bahan pertimbangan bagi pembentukan suatu kawasan sapi potong di Kabupaten Raja Ampat antara lain; (1) ketersedian lahan yang cukup luas termasuk sumber daya tenaga kerja yang sudah menekuni peternakan sebagai bagian dari kegiatan usaha tani (Wiyatna dkk., 2012), (2) kegiatan budidaya sapi potong memiliki prospek bisnis tinggi, (3) produk sapi potong memiliki nilai elastisitas permintaan relatif tinggi terhadap perubahan pendapatan masyarakat (Sahala, dkk., 2016), dan (4) usaha berternak sapi mampu menciptakan kesempatan kerja, kesempatan berusaha dan peningkatan pendapatan, mulai pada agribisnis hulu, budidaya, agribisnis hilir, dan kegiatan jasa terkait seperti transportasi, perbankan, agrotourism dan kegiatan jasa lainnya (Lestari dkk., 2017).

Sapi potong yang banyak terdapat di kabupaten Raja Ampat adalah Sapi Bali umumnya dipelihara secara ekstensif dan bersifat sampingan dari kegiatan usaha tani sebagai usaha utama. Kondisi ini didukung oleh wilayah daratan yang masih luas jika dilihat berdasarkan tingkat kepadatan penduduk di kabupaten Raja Ampat yaitu 7 jiwa/km2 (Dispendcapil Raja Ampat, 2009) dan sumber hijauan makanan ternak serta konsentrat yang belum termanfaatkan. Sistem budidaya sapi potong pada saat ini masih menghadapi berbagai kendala antara lain; (a) kesulitan untuk memperoleh bibit, (b) masih tingginya angka pemotongan ternak betina produktif, (c) rendahnya angka kelahiran dan tingginya angka kematian ternak, (d) rendahnya tingkat keberhasilan teknologi Inseminasi Buatan (IB) (Aryogi dan Romjali, 2010; Romjali, 2018), (e) belum diterapkan teknologi pakan aplikatif, (f) tingginya harga obat hewan, (g) kesulitan untuk akses ke sumber modal, (h) rendahnya nilai tambah yang diperoleh peternak dan (i) masih kurangnya upaya pemanfaatan limbah pertanian dan ternak sebagai sumber pakan, sumber energi dan pupuk organik (Santosa, 2001).

Kebutuhan asal ternak berupa daging, susu dan telur saat ini untuk penduduk Kabupaten Raja Ampat masih disuplai dari Kabupaten Sorong, karena terbatasnya ketersediaan dari dalam. Disparitas antara suplai dan permintaan/kebutuhan menunjukkan bahwa upaya pengembangan sapi potong perlu dilakukan. Hal ini didukung oleh adanya peluang pemasaran daging sapi yang relatif besar untuk perusahaan-perusahaan pertambangan disekitar wilayah Kabupaten Raja Ampat yang siap menerima pasokan daging sapi (Distannakbun Raja Ampat, 2008). Kebutuhan daging sapi untuk PT Freeport Indonesia sebesar 216 ton per bulan, sebagian besar $(70 \%)$ berasal dari Australia, untuk Petrocina Oil sebesar 86 ton per bulan yang semuanya dipasok dari luar Provinsi Papua.

Potensi wilayah yang mendukung dan ketersediaan bahan baku pakan serta sumber daya manusia memungkinkan pengembangan sapi potong berbasis sumber daya lokal di wilayah tersebut. Untuk mengetahui kapasitas wilayah diperlukan adanya kajian mengenai kawasan sapi potong berbasis kerakyatan yang tepat di Kabupaten Raja Ampat sehingga dapat menjadi acuan dalam arah pengembangan sapi potong selanjutnya guna peningkatan kesejahteraan masyarakat Raja Ampat dan pendapatan asli daerah. Penelitian ini bertujuan untuk mengetahui penerapan teknologi budidaya dan komponen-komponen kawasan dalam kaitannya dengan pengembangan sapi potong di kabupaten Raja Ampat.

\section{BAHAN DAN METODE}

Penelitian ini dilaksanakan selama enam bulan dengan lokasi penelitian adalah Kampung Sakabu, Kalobo dan Waijan di Distrik Salawati Utara Kabupaten Raja Ampat Provinsi Papua Barat. Beberapa pertimbangan pemilihan lokasi ini adalah (1) 95\% lebih populasi sapi potong (sapi Bali) berada di lokasi ini, dan (2) berdasarkan RTRW Kabupaten Raja Ampat, lokasi ini diproyeksikan sebagai kawasan agropolitan dengan sentra pengembangan sapi potong di Kabupaten Raja Ampat (Bappeda Raja Ampat, 2007).

Penelitian ini menggunakan metode survei dengan cara pengamatan langsung di lapangan dan melakukan wawancara dengan 218 orang responden atau yang memiliki sapi potong di lokasi penelitan. Kegiatan wawancara dilakukan dengan menggunakan daftar pertanyaan (kuisioner) yang telah disiapkan terlebih dahulu. Pengamatan langsung dilakukan dengan cara melihat secara visual untuk menentukan kondisi dan pola pemeliharaan di lokasi penelitian dan padang penggembalaan.

Data yang dikumpulkan mencakup data sekunder dan primer. Data sekunder selama lima tahun terakhir diperoleh dari Bappeda Kabupaten Raja 
Ampat, Dinas Pertaniaan Peternakan dan Perkebunan Kabupaten Raja Ampat, dan BPS Kabupaten Raja Ampat. Data sekunder tersebut meliputi (1) system penggunaan lahan, (2) karakteristik kelembagaan yang ada dan (3) kebijakan pemerintah daerah dalam pengembangan peternakan. Data primer adalah hasil pengamatan dan pengukuran serta wawancara dengan responden, yakni pola manajemen produksi sapi potong.

Peubah yang diamati dalam penelitian ini meliputi: lahan dan sistem penggunaan lahan, pola manajemen produksi sapi potong; meliputi reproduksi, pemeliharaan dan perkandangan, pakan, penyakit dan kesehatan ternak, pendampingan, sarana dan prasarana, pasca panen dan pemasaran hasil, karakteristik kelembagaan dan kebijakan pemerintah; meliputi kelembagaan peternak dan permodalan, programprogram pemerintah daerah yang menunjang pegembangan peternakan sapi potong.

Data yang diperoleh dianalisis secara deskriptif, dan disajikan dalam bentuk tabel dan gambar. Penentuan model kawasan sapi potong dengan menggunakan kriteria dan indikator komponen kawasan meliputi; (1) lahan; (2) teknis budidaya ; (3) peternak; (4) tenaga pendamping; (5) fasilitas dan (6) kelembagaan. Masing-masing indikator komponen dikuantifikasikan dalam bentuk skor yang diperoleh dari hasil kali antara faktor pembobot dengan nilai yang diberikan pada indikator komponen. Total skor dari semua indikator setelah dibandingkan dengan dengan skor standar kawasan akan digunakan untuk menentukan model kawasan sapi potong. Standar penilaian dilakukan dengan menggunakan pedoman penilaian untuk kawasan pembibitan dan kawasan penggemukan (Priyanto, 2002). Faktor pembobot mempunyai nilai 100 poin yang dialokasikan pada komponen kawasan dan selanjutnya didistribusikan pada setiap indikator komponen. Nilai yang diberikan pada indikator komponen kawasan berkisar antara 0 10 poin sehingga skor tertinggi kawasan sebesar 1000 poin.

Berdasarkan tingkat pengembangan kawasan sapi potong ditetapkan skor standar untuk kawasan baru $<500$, kawasan binaan 500 - 700 dan kawasan pengembangan $>700$ poin. Selain itu nilai skoring tersebut dianalisis menggunakan Analisis Gerombol (Cluster Analisis) untuk memperoleh informasi tentang pengelompokan potensi wilayah sebagai basis sapi potong.

Tabel 1. Penerapan teknologi budidaya (teknis pemeliharaan) sapi potong di lokasi penelitian

\begin{tabular}{|c|c|c|c|c|c|}
\hline \multirow{2}{*}{ No } & \multirow{2}{*}{ Peubah yang Diamati } & \multicolumn{3}{|c|}{ Kampung } & \multirow{2}{*}{ Total } \\
\hline & & Sakabu & Kalobo & Waijan & \\
\hline 1 & Jumlah Peternak (orang responden) & 14 & 118 & 86 & 218 \\
\hline \multirow[t]{5}{*}{2} & Bibit & & & & \\
\hline & a. Seleksi alam $(\%)$ & 100 & 100 & 100 & 100 \\
\hline & b. Sistem Perkawinan & & & & \\
\hline & Kawin alam secara acak & 85,71 & 72,03 & 84,88 & 77,98 \\
\hline & $\begin{array}{l}\text { Kawin alam dengan pejantan } \\
\text { terpilih }\end{array}$ & 14,29 & 27,97 & 15,12 & 22,02 \\
\hline 3 & Sistem pemeliharaan secara ekstensif & 100 & 100 & 100 & 100 \\
\hline \multirow[t]{3}{*}{4} & Pakan & & & & \\
\hline & a. Pemberian hijauan tanpa konsentrat & 82,71 & 95,76 & 96,51 & 95,22 \\
\hline & b. Pemberian hijauan + konsentrat & 14,29 & 4,24 & 3,49 & 4,59 \\
\hline \multirow[t]{3}{*}{5} & Kesehatan dan penyakit & & & & \\
\hline & a. Upaya pencegahan penyakit & 14,29 & 4,24 & 3,49 & 4,59 \\
\hline & b. Penanganan ternak sakit & 14,29 & 5,93 & 4,65 & 5,96 \\
\hline
\end{tabular}

\section{HASIL DAN PEMBAHASAN}

\section{Penerapan Teknologi Budidaya Sapi Potong}

Teknis pemeliharaan sapi potong (sapi Bali) pada lokasi sentra pengembangan sapi potong di kabupaten Raja Ampat (di kampung Sakabu, Kalobo dan Waijan) dapat dilihat pada Tabel 1, yang menunjukkan bahwa sistem pemeliharaan masih bersifat ekstensif dengan cara digembalakan pada areal padang pengembalaan, hutan, persawahan atau perkebunan.

Peternak sapi potong di Sakabu, Kalobo dan Waijan belum melaksanakan seleksi ternak secara terarah, bahkan cenderung menjual ternak dengan ukuran tubuh dan bobot badan yang besar untuk mendapatkan keuntungan lebih banyak. Sistem 
perkawianan umumnya masih secara alami, ada beberapa peternak yang sudah mengawinkan sapi dengan pejantan yang dianggap unggul namun itupun masih secara alami. Sistem perkawinan alami yang tidak terkontrol dapat mengarah pada tingkat silang dalam yang tinggi, menyebabkan anak yang dilahirkan semakin kecil dan kerdil. Rotasi pejantan dari sub populasi berbeda sangat penting dilakukan untuk menghindari silang dalam guna mendapatkan pedet yang sehat dan unggul (Mirza dan Rahayu, 2017).

Kebutuhan pakan seluruhnya tergantung pada hijauan yang tersedia dan dikonsumsi ternak selama merumput. Beberapa peternak memberikan pakan tambahan atau konsentrat berupa dedak, bungkil kelapa, limbah perikanan atau limbah rumah tangga yaitu masing-masing 14.29, 4.24 dan 3.49\% masingmasing di kampung Sakabu, Kalobo dan Waijan. Menurut Prawira dkk. (2015) dalam penelitiannya menyatakan bahwa masukan teknologi pengolahan pakan tidak diaplikasikan dalam melakukan usaha peternakan, hal ini terjadi karena beberapa hal, diantaranya tidak meratanya penyuluhan yang dilakukan oleh pemerintah dan karena sapi potong yang dibudidayakan merupakan usaha sambilan.

Penanganan kesehatan dan penyakit pada ternak dilakukan dengan cara membersihkan ternak atau mengobati sapi yang sakit dengan memberikan obat yang sering digunakan manusia seperti obat cacing combatrin untuk sapi yang cacingan atau antibiotik tetraciclin untuk mengobati diare dengan dosis yang dimodifikasi. Secara umum, sebagian besar $(>85 \%)$ peternak di kampung Sakabu, Kalobo dan Waijan menerapkan tatalaksana pemeliharaan ternak sapi secara semi tradisional dengan campur tangan manusia yang terbatas. Menurut Riady (2004), keterbatasan peternak dalam ilmu pengetahuan dan masalah modal merupakan permasalahan dalam pengembangan sapi potong di Indonesia.

\section{Infrastruktur (Sarana dan Prasarana) Pendukung}

Perintisan peternakan sapi potong di Kabupaten Raja Ampat dimulai pada tahun 2006 melalui pembangunan UPTD-Peternakan. Informasi mengenai identitas dan karakteristik peternak, kontrol kesehatan, upaya penurunan angka kematian, dan pencegahan penyakit ternak sapi potong (sapi Bali) diperoleh melalui pemanfaatan fasilitas kegiatan rutin layanan kesehatan hewan dan pemberian obat-obatan pada hewan/ternak secara berkala menggunakan fasilitas layanan yang tersedia (Tabel 2).

Hasil pengamatan menunjukkan bahwa fasilitas layanan peternakan sapi potong relatif cukup memadai dan perlu dioptimalkan pemanfaatannya. Fasilitas lain seperti cattle yard, holding ground, dan kandang permanen sedang dalam proses pembangunan. Kondisi ini sangat mendukung upaya pengembangan dan pembibitan peternakan sapi potong sebagai suatu kebijakan dan peran aktif pemerintah dalam hal ketersediaan, movilitas, dan jangkauan pelayanan.
Menurut Samariyanto (2004), ketersediaan fasilitas mempengaruhi keberhasilan upaya pengembangan dan pembibitan sapi Bali di suatu wilayah pemeliharaan.

Tabel 2. Fasilitas sarana dan prasarana (infrastruktur) layanan peternakan

\begin{tabular}{lc}
\hline \multicolumn{1}{c}{ Fasilitas } & Jumlah \\
\hline Poskeswan & 1 \\
Rumah potong (RPH) & 0 \\
Gedung Obat-obatan & 1 \\
Dokter hewan (orang) & 1 \\
Petugas peternakan (orang) & 3 \\
Kebun HMT (ha) & 20 \\
Pabrik penggiling padi (unit) & 6 \\
Jalan & Tersedia \\
Pelabuhan & Tersedia \\
\hline
\end{tabular}

\section{Komponen Kawasan Sapi Potong Rakyat}

Karakteristik komponen kawasan peternakan sapi potong berdasarkan tahapan pengembangannya meliputi kawasan baru, kawasan binaan dan kawasan mandiri (Deptan, 2003 dalam Sadiq, 2011). Berdasarkan hasil analisis kawasan sapi potong dengan menggunakan metode skoring memberikan hasil sebagaimana disajikan pada Tabel 3. Dari nilai total skor yang diperoleh, pada kawasan pembibitan dan penggemukan sapi potong di tiga kampung penelitian adalah dibawah 500, yang berarti bahwa ketiga lokasi penelitian diklasifikasikan sebagai Kawasan Baru yang terbagi dalam dua klaster yaitu kelompok Sakabu dan kelompok Kalobo Waijan. Berdasarkan hasil analisis kawasan yang menunjukkan sebagai kawasan baru, kampung Sakabu, Kalobo dan Waijan mempunyai karakteristik komponen kawasan baru yang meliputi lahan dan pakan, peternak, ternak, teknologi serta sarana dan prasarana.

Status kondisi lahan dan pakan (Tabel 3) pada tahapan tradisional di kampung Kalobo, Sakabu dan Waijan terbagi menjadi dua sistem usaha peternakan sapi potong yaitu usaha pembibitan dan penggemukkan. Hasil skor kawasan pembibitan untuk lahan menunjukkan nilai tertinggi (47.5-50), artinya bahwa lahan usaha sepenuhnya di kuasai oleh peternak. Secara keselurahan pada ketiga lokasi belum ada peruntukan lahan secara khusus untuk usaha pembibitan semuanya masih bertumpu pada lahan usaha tani lainnya dan lahan-lahan yang berada di bawah otoritas sektor atau subsekor non peternakan. Umumnya ternak sapi dibiarkan lepas merumput pada lahan bekas sawah dan padang rumput. Pakan utama adalah rumput alami dan sisa hasil pertanian dengan sistem pemeliharan yang bersifat ekstensif. Belum ada usaha kearah budidaya hijauan, begitu pula dengan penyuluhan dan pembinaan yang terprogram oleh 
instansi terkait kearah intergasi usaha peternakan dengan sektor pertanian, perkebunan maupun kehutanan yang secara formil memegang otoritas terhadap lahan-lahan tersebut. Seperti halnya kawasan pembibitan, skor untuk kawasan penggemukan mempunyai nilai yang tinggi (47.5-50). Ditinjau dari segi manajemen pemeliharaan, usaha penggemukan sapi potong relatif lebih bersifat intensif di bandingkan breeding.

Pada ketiga lokasi penelitian, manajemen pemeliharaan oleh peternak belum mengarah kepada sistem penggemukan walaupun hubungan antara status dan kondisi lahan dengan klasifikasi kawasan penggemukan pada hakekatnya tidak berbeda dengan kawasan breeding. Pemanfaatan lahan untuk budidaya hijauan masih belum dijumpai dalam jumlah yang cukup berarti pada ketiga lokasi. Menurut Priyanto (2002), lahan pada kawasan baru umumnya merupakan bagian dari kawasan pertanian tanaman pangan dan holtikutura yang masih jarang ternak ruminansia, namun petani setempat sudah terbiasa menggunakan limbah peternakan seperti pupuk kandang.

Ternak sapi yang dipelihara adalah jenis sapi Bali yang di introduksi pertama kali pada tahun 1979. Dari rata-rata skor nilai ternak untuk kawasan pembibitan dan penggemukan $(<50 \%)$ berada di bawah nilai skor 75 . Hal ini di dukung dengan hasil pendugaan bobot badan menunjukkan bahwa sapi Bali di ketiga lokasi penelitian manunjukan produktivitas yang rendah. Persentase kelahiran (22.32\%) dari populasi dengan tingkat kematian (4.1\%), nilai menunjukkan bahwa tingkat kematian ternak masih relatif tinggi jika dibandingkan dengan tingkat kelahiran $(<5 \%)$. Salah satu ciri dari kawasan baru adalah ternak sapi yang dipelihara memiliki tingkat reproduksi yang rendah yang dicirikan dengan tingkat kelahiran dibawah $50 \%$ dan kematian anak sapi $\geq 15$ $\%$, dan ternak sapi yang dipelihara memiliki tingkat pertumbuhan yang rendah dengan rataan pertambahan bobot badan dibawah $0.5 \mathrm{~kg} / \mathrm{ekor} / \mathrm{hari}$ (Priyanto, 2002).

Tabel 3. Skoring penilaian kawasan pengembangan (penggemukan dan pembibitan) sapi potong

\begin{tabular}{llcccccc}
\hline \multirow{2}{*}{ No } & \multirow{2}{*}{ Kriteria } & \multicolumn{3}{c}{ Skor Penggemukan } & \multicolumn{3}{c}{ Skor Pembibitan } \\
\cline { 3 - 7 } & Sakabu & Kalobo & Waijan & Sakabu & Kalobo & Waijan \\
\hline 1 & Lahan & 50 & 47,5 & 47,5 & 50 & 47,5 & 47,5 \\
2 & Ketersediaan HMT & 150 & 150 & 150 & 150 & 150 & 150 \\
3 & Ternak & 35 & 65,5 & 58,5 & 42 & 86,5 & 79,5 \\
4 & Teknologi budidaya & 67 & 67 & 67 & 80 & 80 & 80 \\
5 & Peternak & 20 & 30 & 20 & 20 & 30 & 20 \\
6 & Tenaga Pendamping & 4 & 4 & 2 & 3 & 3 & 2 \\
7 & Fasilitas & 20 & 55 & 20 & 20 & 55 & 20 \\
8 & Kelembagaan & 5 & 5 & 5 & 5 & 5 & 5 \\
\hline
\end{tabular}

Teknologi budidaya yang dipakai merupakan teknologi pada level produksi subsistem yaitu teknologi input rendah dimana input dan biaya produksi ditekan serendah mungkin. Beberapa hal yang menunjukkan ketiga lokasi ini sebagai kawasan baru dilihat dari aspek teknologi budidaya antara lain ; (1) sapi yang dipelihara adalah jenis sapi lokal (sapi Bali) yang sudah beradaptasi dengan kondisi lingkungan setempat, (2) sistem perkawinan masih kawin alam dan belum ada seleksi ternak yang terarah, (3) pakan yang diberikan terutama hijauan dengan mengandalkan rumput alam yang tidak dibudidayakan atau limbah pertanian, (4) pemeliharaan ternak dilakukan secara ekstensif dengan menggunakan tenaga kerja keluarga, dan (5) penangan kesehatan dan gangguan reproduksi praktis tidak dilakukan dan jika ada bersifat pengobatan.

Tingkat pengetahuan peternak diketiga lokasi penelitian terkait dengan penguasaan teknologi beternak dan keterampilan dalam pengelolaan usaha umumnya masih rendah begitupula dengan motivasi dan kemampuannya dalam mengatasi masalah yang berkaitan dengan manajemen pemeliharaan sapi potong. Umumnya mereka adalah peternak baru, sehingga masih perlu bimbingan dari instansi pemerintah melalui penyuluhan di kelompok peternak. Upaya peningkatan pengetahuan yang bermanfaat bagi peternak adalah pendidikan nonformal berupa kursus dan pelatihan. Kebutuhan tenaga pendamping baik keberadaan atau aksesibilitasnya masih kekurangan. Tingkat aksesibilitas dari kawasan untuk mendapatkan pelayanan dari petugas pendamping yang berada di sekitar lokasi cukup mudah namun keberadaan dari petugas pendamping yang masih sangat kekurangan dan tidak berada setiap saat.

Kelembagaan peternak umumnya masih berupa kelompok pemula yang di bentuk Pemerintah, dalam hal ini Dinas Pertanian dan Peternakan Kabupaten Raja 
Ampat sebagai pelaksana teknis. Peternak dalam kelompok ini baru mengenal kehidupan organisasi/kelompok dan umumnya mereka menjadi anggota bukan atas kemauan atau kesadaran sendiri tetapi lebih disebabkan oleh keinginan untuk menerima bantuan bibit ternak sapi potong dari pemerintah. Tingkat partisipasi anggota kelompok masih rendah karena nilai motivasi dan tingkat pengetahuan dalam peternakan sapi potong yang relatif rendah. Koordinasi pembinaan kelompok masih sepenuhnya masih diatur oleh tenaga pendamping dari pemerintah. Keberadaan kelembagaan keuangan perbankan maupun non bank sangat penting karena merupakan alternatif pembiayaan usaha. Pada ketiga kampung, Sakabu, Kalobo, dan Waijan sepenuhnya belum ada akses permodalan melalui perbankan. Seluruh bantuan kegiatan usaha peternakan sapi potong masih berasal dari program-program pengembangan sapi potong oleh Pemda Kabupaten Raja Ampat. Menurut Saragih (2000) dan Priyanto (2002), upaya mewujudkan kawasan agribisnis peternakan menjadi sumber pertumbuhan ekonomi membutuhkan dukungan ketersediaan sumber-sumber permodalan yang sesuai dengan karakteristik masing-masing usaha. Sesuai dengan tingkat pengembangannya pada kawasan baru umunya peternak belum banyak mengenal atau berhubungan dengan lembaga keuangan terutama yang formal. Langkah pertama yang harus di lakukan adalah memperkenalkan bank kepada peternak melalui bantuan permodalan dalam bentuk dana bergulir dengan system penyaluran langsung bank ke kelompok peternak. Bantuan permodalan tidak hanya mengandalkan Pemerintah tetapi juga dari pihak swasta dan masyarakat. Bentuk kerjasama permodalan yang sesuai bagi kelompok peternak pemula di kampung Sakabu, Kalobo dan Waijan adalah sistem bagi hasil dalam bentuk perguliran ternak.

Sistem pegelolaan peternakan sapi potong oleh peternak di kampong Sakabu, Kalobo dan Waijan masih bersifat ekstensif, tidak ada recording ternak dan pembukuan usaha, hal ini karena tingkat pendidikan peternak yang relative rendah. Dalam hal perencanaan, peternak belum dapat menyusun rencana usaha jangka pendek maupun jangka panjang, tidak bisa meramalkan tingkat produksi maupun biaya produksi yang harus disediakan untuk tahun-tahun yang akan datang. Kondisi ini disebabkan tujuan beternak sapi potong oleh peternak hanya sebatas sebagai tabungan atau cadangan penghasilan yang akan digunakan sewaktu-waktu.

Fasilitas penunjang dasar seperti holding ground, pos keswan, laboratorium diagnostik dan kandang karanrtina ternak telah di bangun di Unit Pelaksnana Teknis Daerah (UPTD) Sapi Potong di Kampung Kalobo, namun fasilitas ini belum dapat dipergunakan sebagaimana mestinya karena keterbatasan sumber daya manusia yang mengelolanya. Aksesibilitas ke fasilitas penunjang ini di dukung dengan jalan yang cukup memadai terutama dari kampung Sakabu dan Waijan. Penyaluran sarana produksi peternakan terutama vaksin dan obat-obatan sepenuhnya masih di tangani pemerintah dalam bentuk bantuan layanan kesehatan hewan.

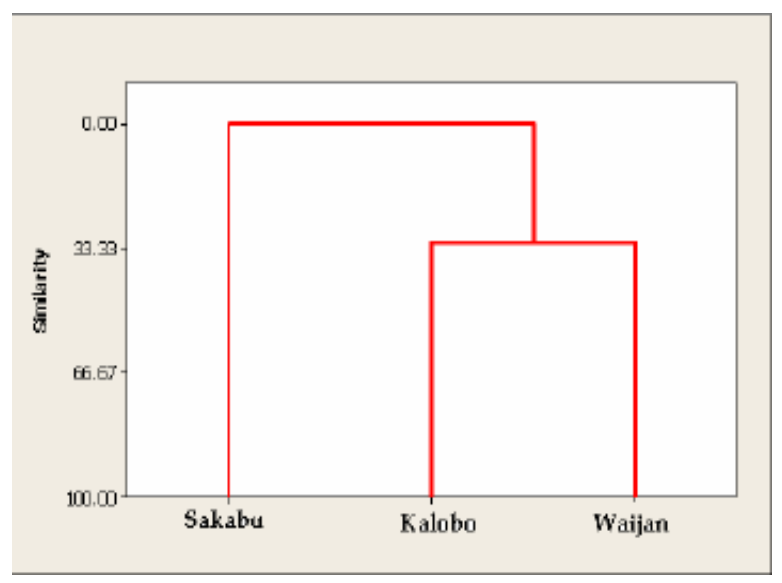

Gambar 1. Dendogram hasil analisis klaster kawasan pengembangan sapi potong pada lokasi penelitian

Berdasarkan hasil analisis klaster (Gambar 1), menunjukkan bahwa kampung Sakabu mempunyai karakteristik yang berbeda di banding Kalobo dan Waijan. Hal ini disebabkan beberapa komponen kawasan yang meliputi ternak, teknologi budidaya, dan peternak mempunyai nilai skoring terrendah dibanding kampung Kalobo dan Waijan. Kondisi ini lebih dipengaruhi oleh pengalamam beternak, karena peternak di kampung Sakabu umumnya adalah peternak yang baru mulai mencoba memelihara ternak sapi potong. Kondisi lahan dan topografi serta komponen penyusun kawasan lainya relatif sama, kecuali sarana dan prasarana penunjang peternakan hanya tersedia di kampung Kalobo, namun hal ini tidak terlalu bermasalah karena aksesibilitas dari Sakabu dan Waijan ke kampung Kalobo relatif mudah.

Menurut Priyanto (2002), dan Bappenas (2004), kawasan peternakan sapi potong secara khusus diperuntukkan bagi kegiatan usaha sapi potong, terintegrasi dengan komponen usaha tani atau ekosistem tertentu, dan dalam pengembangannya banyak melibatkan partisipasi rakyat dengan mengoptimalkan potensi sumberdaya lokal yang ada. Data pada Tabel 3 menunjukkan, bahwa sebagai kawasan baru, optimalisasi pemanfaatan semua sumber daya yang tersedia dan didukung penerapan teknologi aplikatif akan mampu meningkatkan peran ternak sebagai usaha alternatif bagi masyarakat.

\section{SIMPULAN DAN REKOMENDASI}

Berdasarkan hasil penelitian dapat ditarik beberapa kesimpulan sebagai berikut : (1) sistem pemeliharaan masih bersifat ekstensif dengan cara digembalakan pada areal padang pengembalaan, hutan, persawahan atau perkebunan; (2) peternak sapi potong 
belum melaksanakan seleksi ternak secara terarah, dan sistem perkawianan umumnya masih secara alami; (3) aplikasi teknologi pengolahan pakan belum diterapkan secara baik dan benar; dan (4) berdasarkan total skor yang diperoleh, kawasan pembibitan dan penggemukan sapi potong di kabupaten Raja Ampat adalah dibawah 500, yang diklasifikasikan sebagai Kawasan Baru.

Guna menunjang keberhasilan program pengembangan kawasan ternak sapi potong di Kabupaten Raja Ampat, beberapa hal penting perlu segera diupayakan yaitu; menyusun model pengembangan kawasan sapi potong ; sumber daya manusia yang berkualitas, teknologi budidaya sapi potong, fasilitas pembibitan ternak dan pengembangan sistem pemuliabiakan, fasilitas kandang karantina ternak/hewan, fasilitas layanan kesehatan berupa poskeswan dan dokter hewan, pasar dan pemasaran, kemitraan usaha, lembaga keuangan dan permodalan.

\section{DAFTAR PUSTAKA}

Aryogi, dan E. Romjali. 2010. Potensi, Pemanfaatan dan Kendala Pengembangan Sapi Potong Lokal sebagai Kekayaan Plasma Nutfah Indonesia. Lokakarya Nasional Pengelolaan dan Perlindungan Sumber daya Genetik Di Indonesia: Manfaat Ekonomi untuk Mewujudkan Ketahanan Nasional. Hlm: 151166.

[Bappeda] Badan Perencanaan Pembangunan Kabupaten Raja Ampat. 2007. Rencana Tata Ruang Wilayah Kabupaten Raja Ampat. Waisai: Pemerintah Daerah Kabupaten Raja Ampat.

[Bappenas] Badan Perencanaan dan Pembangunan Nasional Direktorat Pengembangan Kawasan Khusus dan Tertinggal. 2004. Tata Cara Perencanaan Pengembangan Kawasan. Jakarta: Bappenas.

[Deptan] Departemen Pertanian Republik Indonesia Direktorat Bina usaha Petani Ternak dan Pengolahan Hasil Peternakan. 2002. Usaha Peternakan; Perencanaan Usaha, Analisa, dan Pengelolaan. Jakarta: Deptan.

[Dispendcapil] Dinas Kependudukan dan Catatan Sipil 2009. Laporan Triwulan I (Januari-April 2009). Waisai:Pemerintah Kabupaten Raja Ampat.

[Distannakbun] Dinas Pertanian Peternakan dan Perkebunan Kabupaten Raja Ampat. 2008. Laporan Tahunan Kegiatan Peternakan 2007. Waisai: Pemerintah Kabupaten Raja Ampat.

Lestari, R. D., L. M. Baga, dan R. Nurmalina. 2017. Daya saing usaha penggemukan sapi potong peternakan rakyat di Kabupaten Bojonegoro, Jawa Timur. Buletin Peternakan. 41: 101-112.

Mirza, I., dan K. Rahayu. 2017. Model Pengembangan Kawasan Peternakan Sapi Aceh di Kabupaten Aceh Jaya Propinsi Aceh. Jurnal Peternakan Indonsia. 19(3): 156-164.

Prawira, H.Y., Muhtarudin, dan R. Sutrisna. 2015. Potensi Pengembangan Peternakan Sapi Potong Di Kecamatan Tanjung Bintang Kabupaten Lampung Selatan. Jurnal Ilmiah Peternakan Terpadu. 3(4): 250-255.

Priyanto R. 2002. Penyusunan Standart Kawasan Agribisnis Peternakan dalam Rangka Pengembangan Sistem Informasi. Jakarta: Fakultas Peternakan IPB dan Ditjend Bina Produksi Peternakan Deptan RI.

Putu, I.G., Dewyanto, P. Sitepu, dan T.D. Soedjana. 1997. Ketersediaan dan Kebutuhan Teknologi Produksi Sapi Potong. Proceeding Seminar Nasional Peternakan dan Veteriner; Bogor, 78 Januari 199. Hlm: 50-63.

Riady, M. 2004. Tantangan dan peluang peningkatan produksi sapi potong menuju 2020. Di dalam: Strategi Pengembangan Sapi Potong dengan Pendekatan Agribisnis dan Berkelanjutan. Prosiding Lokakarya Nasional Sapi Potong; Yogyakarta, 8-9 Oktober 2004. Hlm: 3-6.

Romjali, E. 2018. Program pembibitan sapi potong lokal di Indonesia. Wartazoa. 28(4): 199-209.

Sadiq, A. 2011. Analisis Kawasan Usaha Pengembangbiakan dan Penggemukan Sapi Potong Berbasis Sumberdaya Lokal Pedesaan untuk Program Nasional Percepatan Pencapaian Swasembada Daging Sapi. J. Agripet. 11(1): 22-29.

Sahala, J., R. Widiati, dan E. Baliarti. 2016. Analisis kelayakan finansial usaha penggemukan sapi simmental peranakan ongole dan faktor-faktor yang berpengaruh terhadap jumlah kepemilikan pada peternakan rakyat di Kabupaten Karanganyar. Buletin Peternakan. 40: 75-82.

Samariyanto, 2004. Alternatif kebijakan pembibitan sapi potong dalam era otonomi daerah. Di dalam: Strategi pengembangan sapi potong dengan pendekatan agribisnis dan berkelanjutan. Prosiding seminar nasional sapi potong; Yogyakarta, 8-9 Oktober 2004. Hlm: 7-13.

Santosa, U. 2001. Prospek Agribisnis Penggemukan Pedet Jakarta: Penebar Swadaya.

Saragih, B. 2000. Agribisnis Berbasis Peternakan 
(Kumpulan Pemikiran). Bogor: Pusat Studi Pembangunan IPB dan USESE Foundation.

Wiyatna, M. F., A. M. Fuah, dan K. Mudikdjo. 2012.
Potensi Pengembangan Usaha Sapi Potong Berbasis Sumber daya Lokal di Kabupaten Sumedang Jawa Barat. J. Ilmu Ternak. 12(2): $16-21$.

Available online at journal homepage: http://ojs3.unpatti.ac.id/index.php/agrinimal 